\title{
STATISTICAL REASONING OF VARIABILITY IN THE NARRATIVE PERSPECTIVE OF STUDENTS
}

\section{PENALARAN STATISTIS DALAM PERSPEKTIF NARATIF MAHASISWA TENTANG VARIABILITAS}

\author{
RAHMATINA, Desi ${ }^{1,6}$; NUSANTARA, Toto ${ }^{*}$; PARTA, I Nengah ${ }^{3}$; SUSANTO, Hery ${ }^{4}$; AS'ARI, \\ Abdur Rahman ${ }^{5}$
}

${ }^{1}$ Doctorate Program of Mathematics Education, Universitas Negeri Malang, Faculty of Mathematics and Natural Sciences, Department of Mathematics, Indonesia

2,3,4,5 Universitas Negeri Malang, Faculty of Mathematics and Natural Sciences, Department of Mathematics, Indonesia

${ }^{6}$ Universitas Maritim Raja Ali Haji, Faculty of Teacher Training and Education, Department of Mathematics Education, Indonesia.

\author{
${ }^{*}$ Corresponding author: \\ e-mail: toto.nusantara.fmipa@um.ac.id
}

Received 19 August 2020; received in revised form 22 September 2020; accepted 23 October 2020

\section{RESUMO}

O raciocínio estatístico é a maneira como as pessoas raciocinam com ideias estatísticas e dão sentido às informações estatísticas. O raciocínio estatístico desempenha um papel importante e é essencial quando os indivíduos se deparam com fenômenos diários, como o desempenho educacional. A variabilidade é um componente fundamental do raciocínio estatístico. Este estudo teve como objetivo investigar o processo de raciocínio estatístico observado a partir da narração dos alunos a partir da tarefa de variabilidade. O processo de raciocínio estatístico utilizado neste estudo consiste na análise e interpretação dos dados. Existem três indicadores usados no processo de raciocínio estatístico, a saber, a narrativa dos alunos na comparação da variabilidade, fazendo conclusões e tomando decisões com base no gráfico ogiva. Participaram deste estudo 108 alunos da Educação Matemática, dos quais 49 foram selecionados como sujeitos da pesquisa. O sujeito foi escolhido porque havia realizado um processo de raciocínio estatístico usando narrativa com "fazer sentido" sem fazer cálculos matemáticos na conclusão da tarefa. Dois dos 49 alunos foram selecionados para serem entrevistados. Este estudo utilizou dois instrumentos, a saber, uma tarefa escrita e um roteiro de entrevista semiestruturada. Os dados foram analisados por meio de métodos qualitativos com desenho exploratório descritivo. Os resultados deste estudo indicam que duas formas de narrativa emergem quando os alunos empreendem um processo de raciocínio estatístico, a saber, uma narrativa consistente e uma narrativa inconsistente. A narrativa consistente ocorre quando os alunos podem fornecer a mesma narrativa endossada sobre a variabilidade em cada processo de raciocínio estatístico. Enquanto isso, a narrativa inconsistente ocorre quando os alunos fornecem uma narrativa endossada, que é o oposto entre comparar a variabilidade nos dois grupos de dados com a narrativa endossada na tomada de decisões. A inconsistência narrativa resulta na tomada de decisão errada na escolha de um dos dois grupos de dados. Uma narrativa consistente desempenha um papel essencial na tomada de decisão certa. A capacidade de usar conceitos estatísticos é necessária para produzir uma narrativa consistente.

Palavras-chave: raciocínio estatístico, variabilidade, narrativa, narrativa consistente, narrativa inconsistente

\section{ABSTRACT}

Statistical reasoning is the way people reason with statistical ideas and make sense of statistical information. Statistical reasoning plays a major role and is essential when individuals are faced with daily phenomena such as educational achievement. Variability is a fundamental component of statistical reasoning. This study aimed to investigate the process of statistical reasoning observed from the students' narration based on the task of variability. The statistical reasoning process used in this study is in analyzing and interpreting the data. There are three indicators used in statistical reasoning, namely students' narrative in comparing variability, making conclusions, and making decisions based on the ogive graph. There were 108 students involved in this 
study in Mathematics Education; 49 were selected as research subjects. The subject was chosen because they had carried out a statistical reasoning process using narrative with "make sense" without doing mathematical calculations in completing the task. Two of the 49 students were selected to be interviewed. This study used two instruments, namely a written task and a semi-structured interview guide. The data were analyzed using qualitative methods with an exploratory, descriptive design. This study indicates that two forms of narrative emerge when students undertake a process of statistical reasoning, namely a consistent narrative and inconsistent narrative. The consistent narrative occurs when students can provide the same endorsed narrative about variability in each statistical reasoning process. Meanwhile, the inconsistent narrative occurs when students provide an endorsed narrative, which is the opposite of comparing the variability in the two data groups with the endorsed narrative in making decisions. Narrative inconsistency results in the wrong decision making in choosing one of the two groups of data. A consistent Narrative plays an essential role in making the right decision. The ability to use statistical concepts is needed to produce a consistent narrative.

Keywords: statistical reasoning, variability, narrative, consistent narrative, inconsistent narrative

\section{ABSTRAK}

Penalaran statistis merupakan cara orang menalar dengan ide-ide statistis dan membuat sense terhadap informasi statistis. Penalaran statistis memainkan peranan utama dan sangat esensial ketika individu dihadapkan pada fenomena sehari-hari, seperti pencapaian pendidikan. Variabilitas merupakan komponen penting dalam penalaran statistis. Tujuan kajian ini adalah untuk menginvestigasi proses penalaran statistis ditinjau dari naratif mahasiswa berdasarkan tugas tentang variabilitas. Proses penalaran statistis yang digunakan dalam kajian ini adalah menganalisis dan menginterpretasi data. Ada tiga indikator yang digunakan dalam proses penalaran statistis tersebut, yaitu narrative mahasiswa dalam membandingkan variabilitas pada dua kelompok data, membuat kesimpulan, dan membuat keputusan berdasarkan grafik ogive. Mahasiswa yang terlibat dalam kajian ini sebanyak 108 mahasiswa Pendidikan Matematika, 49 diantaranya dipilih sebagai subjek penelitian. Subjek tersebut dipilih karena mereka telah melakukan proses penalaran statistis menggunakan narrative dengan "make sense" tanpa melakukan perhitungan matematis dalam menyelesaikan tugas. Dua dari 49 mahasiswa dipilih untuk diwawancarai. Kajian ini menggunakan dua instrument yaitu tugas tertulis dan pedoman wawancara semiterstruktur. Data dianalisis menggunakan metode kualitatif dengan pendekatan deskriptif eksploratif. Hasil kajian ini menunjukkan bahwa ada dua bentuk narrative yang muncul ketika mahasiswa melakukan proses penalaran statistis, yaitu narrative konsisten dan narrative inkonsisten. Narrative konsisten terjadi ketika mahasiswa dapat memberikan endorsed narrative yang sama tentang variabilitas pada setiap proses penalaran statistis. Sedangkan narrative inkonsisten terjadi ketika mahasiswa memberikan endorsed narrative yang bertolak belakang antara membandingkan variabilitas pada dua kelompok data dengan endorsed narrative saat membuat keputusan. Narrative inkonsisten berakibat kepada pengambilan keputusan yang keliru dalam memilih salah satu dari dua kelompok data. Narrative konsisten memegang peranan penting dalam membuat keputusan yang tepat. Kemampuan dalam menggunakan konsep-konsep statistis sangat diperlukan untuk dapat menghasilkan narrative yang konsisten.

Kata kunci : penalaran statistis, variabilitas, naratif, naratif konsisten, naratif inkonsisten

\section{INTRODUCTION:}

Statistical reasoning plays a major role and is essential when individuals are faced with daily phenomena (Bennett et al., 2017) such as economic growth, the spread of diseases, production of goods, education achievement, and employment trend. Therefore, statistical reasoning has been a part of many studies, including the business field (Hoerl and Snee, 2012), education (Coladarci, 2014), law (Gastwirth, 1988), and health (Gagnier and Morgenstern, 2017). Thus, reasoning skills are necessary competencies that students must acquire in studying mathematics (NCTM, 2000).

Statistical reasoning is how people think with statistical ideas and make sense of statistical information (Garfield and Ben-zvi,2008).
Meanwhile, Kalobo (2016) states that statistical reasoning involves making interpretations based on the collected data or summary of the statistical data. The students need to combine various ideas about data and probability to draw conclusions and interpret statistical results. Statistical reasoning is one of the pertinent learning outcomes in statistics education (Saidi and Siew, 2019). Thus, statistical reasoning can be defined as a person's logical thinking process about analyzing and interpreting data so that a conclusion is reached.

Related to that, variability is one major factor in statistical reasoning (Garfield and Ben-Zvi, 2008; Wells, 2018). Therefore, variability is essential in statistical reasoning. Due to the importance of the variability, the researchers chose the variability in this study because it is the foundation to understand other concepts in 
statistics (Burrill and Biehler, 2011; Garfield and Ben-Zvi,2008). Moreover, Ekol and Sinclair (2016) stated that reasoning about graphs, means, medians, and standard deviations in descriptive statistics requires understanding the variability.

Variability is studied in descriptive statistics at the university level (Cooper, 2018; Sánchez et al., 2011). These materials are the main components in solving inferential statistics problems (Garfield and Ben-Zvi,2008). For example, in hypothesis testing, sampling distribution, correlation, and regression tests, a good mastery of the variability concept is necessary. One example of the need for variability in hypothesis testing is when comparing the average math test scores between a group of students studying online as a form of distance learning with a group of students studying face-to-face in class, whether there is a significant difference in the average mathematics scores of the two groups of these students or not. In this case, the concept of variability is needed to determine how the variance value in the two data groups. The variance value is one of the variability measures, which is useful for calculating the appropriate statistical value in conducting the hypothesis testing process for two sample groups (Pfannkuch, 2011; Waigandt and Wang, 2010). Besides, the researchers also chose college students as research subjects (e.g., DelMas, R. C., and Liu, Y., 2007; Reading and Reid, 2007; Cooper, 2018; Ekol and Sinclair, 2016) because the concept of the variability is employed by this group of students on an ongoing basis from the lowest to the highest levels of semesters.

Nonetheless, although the reasoning is the main competence that must be possessed since the students are at school, they still have poor statistical reasoning abilities (Chan et al., 2014). The students also misunderstand statistical concepts such as understanding probability (Khazanov and Prado, 2010), p-value, and significance (Gagnier, 2017) and random sampling (Karupiah, 2015). Furthermore, the students misunderstand the concepts of interpreting the variability (Cooper and Shore, 2010; Hjalmarson et al., 2011) in histograms, bar charts, and the values in them (Cooper, 2018).

Previous researchers have conducted studies on statistical reasoning among college students about variability (e.g., Reading and Reid, 2007; Cooper, 2018; Ekol and Sinclair, 2016). The focus of the study conducted by Reading and Reid (2007) was to reveal how the students did their reasoning about variability by using clarification, intuition, inquiry, and cognitive conflict. Meanwhile, Cooper (2018) investigated the students' conceptions and misconceptions in interpreting variability in several groups of data displayed in the form of histograms, bar graphs, and the values of the bars. The misconceptions occurred during the observation of the height of the bars. The students predicted that higher bars represented higher variability values. The students used graph sense without performing mathematical calculations in comparing the variability of several groups of data on the histogram (Cooper, 2008), bar charts (Cooper, 2018), Chalkboard charts are based on data arising from scientific phenomena (Roth and Temple, 2014 ). Moreover, Ekol and Sinclair (2016) used Individual Meaning Building (IMB) to analyse the variation of data in a video. The students were able to demonstrate the ability to express standard deviations when faced with changes in graphic and numeric forms in the video. The ability to express changes in objects, as shown in the video, according to Nardi (2016), is called narrative. Lampen (2015) stated that the main factor in statistics is narrative about variation between distributions.

The narrative is a series of expressions that describe objects, processes, and relationships between objects (Sfard, 2008; Nardi, 2016) or activities with or by objects, which could be accepted or rejected within the mathematical discourse (Swidan and Daher, 2019). Objects are all types of entities related to students, teachers, and other stakeholders, while the examples of the narrative are mathematical definitions or theorems labeled with endorsed narratives (Toscano et al., 2019). Furthermore,(Roberts and le Roux, 2019; Tasara, 2017) states that endorsed narrative can be in the form of theories, definitions, proofs, and theorems.

Furthermore, Few and Edge (2009) also state that narrative is to tell a story based on quantitative information, which involves numbers; this kind of narrative is called statistical narrative. Whereas, Noll et al. (2018) argue that statistical narrative is a story in constructing and interpreting statistical models. Noll et al. (2009) examine how students' narratives when confronted with the context of playing piano notes and relating them to the features of the TinkerPlots software.

Zayyadi et al. (2019) researched students' ability to solve mathematical problems from a commognitive perspective. The form of the narrative was indicated when the students explained the theorem of a rectangular area using the concepts of addition and subtraction. Similarly, Lampen (2015) studied the narrative of the concept of statistics in a teacher. He found that 
initially, the teacher could not create narratives about the mean as a statistical object. The teacher's explanation was mixed among the mean and other measures of distribution. Through a focused discussion about the mathematical structure of the mean algorithm, the teacher could finally construct a narrative about the mean as a constant.

In carrying out statistical reasoning, the ability to narrate statistical concepts and information is necessary. When someone can perform good statistical reasoning, he/she naturally possesses expertise in narrating how to describe data, organize and reduce data, represent data, and analyze and interpret data. Kalobo (2016) states that statistical reasoning is understanding and explaining the statistical process and interpreting statistical results. In this case, it can be concluded that the ability to narrate is directly proportional to the ability to understand and explain the statistical process.

The narrative concerning this research is the expression in the form of a story or words to describe the process of statistical reasoning in analyzing and interpreting the data displayed in the form of an ogive graph. In the ogive graphic display, students provide arguments or narratives related to variability. Narratives expressed by students based on numerical information on the ogive graph are called statistical narratives.

When someone does a narrative on a concept, it can be contradictory between one statement to another. In line with the research conducted by Tasara (2018), his research shows that teachers explain different word use gradients in the learning process. As a result, students have difficulty in understanding the meaning of the gradient. Researchers suspect that the narrative's inconsistency can occur in the learning process when the teacher explains the subject matter about mathematical concepts. However, the inconsistent narrative can occur in reasoning when someone explains the concept of statistics. For example, students narrate the definition of variability correctly when comparing the variability of several groups of data. However, the rules related to the expressed variability could change when they are making decisions.

Furthermore, Tasara (2018) states that the risks arising from the inconsistent narrative by the teacher are students having difficulty in understanding a concept. Difficulty in understanding concepts results in the difficulty of students doing the process of statistical reasoning. This is because statistical reasoning is based on understanding statistical concepts (Tempelaar et al., 2006). Students who have good statistical reasoning can express the relationships between statistical concepts (Chance and Garfield, 2001). This shows that the difficulty in understanding the concept due to inconsistent narrative can properly affect someone's difficulty in statistical reasoning. Due to the risk resulting from the inconsistent narrative, the researcher needs to examine from a different perspective from the previous researcher about the narrative.

Tasara (2018) examines the teacher's narrative in explaining the gradient concept in calculus. In this study, researchers examine how students' narratives in conducting a statistical reasoning process about variability. In contrast to Tasara (2018), subjects in their research are not required to connect several concepts in narrating the gradient concept. Whereas in this study, subjects are required to link the relationship of several concepts, such as the relationship between the concept of variability with the mean, median, mode, and concept of normal distribution. The ability to connect among concepts is one characteristic of statistical reasoning (Hidayanto and Rahmatina, 2020).

The narrative plays a vital role in reasoning (Saletta et al., 2020), including statistical reasoning. This is based on the fact that someone is said to have carried out statistical reasoning if they already possessed the characteristics of the statistical reasoning, including being able to connect several concepts, combining various ideas, understanding steps to solve problems, and being able to explain the statistical process (Hidayanto and Rahmatina, 2020). For example, someone who can connect several concepts must be accompanied by his ability to communicate what concepts are involved in solving a problem. Sfard (2008) named the ability to communicate what is thought as commognitive, where one of the frameworks of commognitive is narrative.

This study investigates how the process of statistical reasoning is reviewed from students' narratives based on task about variability. The task was given to students whose data display was in the form of an ogive graph. Statistical reasoning is seen from the "make sense" of students in analyzing and interpreting statistical information on an ogive graph without mathematical calculations.

This study is essentially needed, especially useful for decision-makers such as teachers, principals, and related parties in making decisions when faced with having to choose one group from 
several data groups. For example, suppose a principal is given two graphs that contain information on mean, median, and equally large mode values. In that case, he/she then can decide which group of students has more equitable performance and which group should be selected. Therefore, the use of a statistical narrative of graph sense becomes an alternative to make decisions in a short time. In this case, understanding the concept of variability is certainly necessary to the endorsed narrative the form of the graph following the rules of variability.

This study aimed to investigate the process of statistical reasoning on the concept of variability by using narratives. The narrative used by students is in the form of statistical narrative because the expression or argument is based on quantitative information from the display of data in the form of an ogive graph.

\subsection{Theoretical Framework}

The narrative in this study refers to the Sfrad commognitive framework. Sfard (2008) stated that thinking is communication, for example, communicating objects, the mediators used, and the rules. Furthermore, Sfard (2008) also stated that the combination of the words: "communication and cognition" are called commognitive. The commognitive capacity is divided into two categories, namely those related to commognitive objects (such as reasoning, abstracts, and objectification) and those related to commognitive subjects (such as subjectivity and awareness).

The commognitive framework, according to Sfard (2008), consists of Word Use, Visual Mediator, Narrative, and Routine. The researchers limit this study by only using a commognitive framework in the form of narrative to investigate students' statistical reasoning processes about variability. The statistical reasoning indicators in the narrative perspective used in this study were modified from the indicators of the statistical reasoning of Jones et al. (2004), as described in Table 1.

\section{MATERIALS AND METHODS:}

\subsection{Participants}

There were 108 students involved in this study (Male: 26 students; female: 82 students; aged 19-21 years) in the fourth semester (two classes) and sixth semester (two classes) of the Mathematics Education Study Program at the Raja Ali Haji Maritime University, Tanjung Pinang, Indonesia. Of the 108 students, 49 students (male:
9; female: 40: aged 19-21 years) were selected as research subjects. Garfield and Ben-zvi (2008) stated that statistical reasoning is making sense of statistical information. Therefore, in this study, the subjects were chosen based on the criterion of having carried out statistical reasoning using statistical narratives in completing tasks about variability by making sense without doing mathematical calculations. Fifty-nine participants were not used as research subjects because they could not complete the task entirely and could not make sense in completing the task. The profile of the participants and the subjects are shown in Table 2. All of the participants took a course in introduction to statistics in the previous semester, and variability was one of the subjects studied. This study was conducted in 2019.

Two of the 49 subjects were chosen to be interviewed in-depth about the narrative they expressed in the statistical reasoning process. There are 25 of the 49 subjects who have the similarity endorsed narrative in comparing variability based on the ogive graph, but having differences in the narrative in making decisions to choose a group that should receive awards. Of those the 25 subjects, there was one subject who chose group A, and 24 subjects chose group B. Therefore, the researcher chose the only one subject who chose group A (S1: female) and randomly chose one of 24 subjects who chose group B (S2: male) to be interviewed. The S2 subject selection as the second subject was due to the same narrative tendency with the other subjects in choosing group $\mathrm{B}$. The procedure for taking the subjects can be seen in Figure 3.

\subsection{Instrument}

There were two instruments used in this study, including written task and interview guidelines. The task contained a question about variability given classically and worked individually. The task was shown in Figure 1. The task contains one question about variability that was displayed in the form of a positive ogive graph. The subjects were asked to choose one of the two data groups and conclusions obtained from the information on the ogive graph (e.g., graph form, number of students around the center of data, and the scores on the graph).

Both groups had the same mean, median, and mode, within and between the groups. Interview guidelines were made to reveal the student's statistical reasoning process about variability in the narrative perspective in depth. This study used a semi-structured interview method in which the researchers used interview 
guidelines (see Table 4) and asked more flexible questions according to the information needed.

\subsection{Data Collection Procedure}

This study was initial research on the first researcher's dissertation. Besides being a Ph.D. student, the first researcher is also a lecturer in the mathematics education study program at Raja Ali Haji Maritime University. The first researcher requested permission verbally from the head of the Mathematics Education study program at the Raja Ali Haji Maritime University so that researcher could conduct this study. Furthermore, the first researchers asked for the lecturer's time who taught in the fourth semester and the sixth semester in the study program so that the researcher could enter the class to meet the respondents. After agreeing with the possible time, the first researcher entered the classroom to ask students for a willingness to be involved in this study. After students declared their willingness, the first researcher assigned the task to students and supervised them directly in doing the task. After the students worked on the task, the first researcher asked the willingness of two of the forty-nine students to be interviewed. After they stated their willingness, the first researcher and the students agreed regarding the time and place of the interview.

Data sources used in this study were the answers to the written task and the results of the interviews. Initially, the first researcher directly supervised the students while they worked on the task and interviewed respondents. The task was given to students to investigate students' statistical reasoning processes about variability and investigate how students expressed written narratives in this statistical reasoning. Meanwhile, interviews were conducted to obtain more in-depth information about statistical narratives used by respondents in statistical reasoning.

The procedure in collecting data was carried out through the following stages: In the first step, the researchers reduced the data by sorting out the answers of the students who did not use the process of statistical reasoning from those who used the process of statistical reasoning. In the second step, the researchers classified the answers using the statistical reasoning process of variability based on statistical narrative. Students used to make sense without doing mathematical calculations in completing the task. In the third step, the researchers collected the results of the interviews recorded using a voice recording device on the cell phone. The interviews were conducted with two students for 25-40 minutes each.

\subsection{Data Analysis Procedure}

This study used qualitative methods with explorative (Creswell, 2012), descriptive designs in which researchers investigate, describe, and interpret student reasoning processes about variability. The data analysis process was carried out in three stages. In the first step, the researchers investigated the students' statistical reasoning processes to analyze and interpret data about variability using statistical narrative. In the second step, the interview transcriptions were analyzed based on the task. In the third step, the researchers made conclusions based on research findings.

\section{RESULTS AND DISCUSSION:}

Analyzing and interpreting data are the main statistical reasoning (Jones et al., 2004). The scope of this process includes identifying trends, making conclusions, data predictions (Jones et al., 2004), and making decisions. Students' narratives in analyzing and interpreting data are shown when the students: 1) revealed a comparison of the variability in the two data groups displayed in an ogive graph. 2) explained conclusions from comparing the observed ogive forms, and 3) narrated a decision on which group should receive awards.

In comparing the variability of mathematics value displayed in ogive, the students' statistical narratives are shown when they explain the comparisons. The variability can be seen from the shape of the ogive curve. Only one subject (S1) narrated the small measure of variability if their frequency is mostly at around the center value and higher measure of variability if fewer students gather around the center value, as seen in Figure 2 . This shows that the students can use statistical reasoning by comparing the tool of variability displayed in an ogive graph. However, subjects narrated that the measure of variability is high if the curve shape is not substantially arching; the curve rises stably in the range of 60.5-70.5.

The next process in analyzing and interpreting the data is to draw a conclusion based on variability. Some subjects used statistical narrative the conclusion that good data distribution is where the curve shape is not substantially arching, the curve rises stably. The data distribution is not only centered. Only one subject (S1) concludes that a good data distribution occurs if there were more students' scores gathered around the data center.

The last process in analyzing and 
interpreting the data is to decision making. Decision making is essential in the process of statistical reasoning. Making a wrong decision would cause a mistake in giving a reward to those who do not deserve it. Many students (25 subjects) reveal the graph where the students' scores gather around the center value, receiving the awards. Besides, as many as 24 students revealed that group B should receive awards because student scores in group B were more evenly distributed in each range of student grades. Student's interpretation in making the decision is displayed in Table 3.

From Table 3, it appears that there are 25 subjects chose group $A$ which was entitled to the award because the line shape on the ogive graph of group A rose dramatically, and more students gathered around the average. Only one student (S1) of the 25 students revealed that group A variability was smaller than group $B$ variability. Moreover, 24 students (one of them is S2) chose group $B$, which was entitled to receive the award because the ogive graph of group $B$ statically rose. The students stated that group B's variability in group $B$ was higher than the variability in group $A$.

There are differences in the narrative expressed by the subjects in statistical reasoning from the two groups of subjects' answers (choosing group A and choosing group B). Three forms of endorsed narrative are used by subjects in choosing one of two data groups (group $A$ or group B). First, the subject chose group $A$ because group A variability was smaller than B group variability (narrative subject $S 1$ ). Second, the subject chose group $A$ because group A variability was higher than the variability of group $B$. Third, the subject chose group $B$ because variability in group B was higher than variability in group A (narrative on 24 subjects). In this third narrative, all subjects had the same narrative tendency in carrying out statistical reasoning; for this reason, the researcher chose one of the 24 subjects, the S2 subject, to be interviewed. The first researcher interviewed S1 and S2 subjects to obtain in-depth information about narratives expressed by subjects related to decision making. The selection of $S 1$ and $S 2$ subjects was due to the same narrative tendency in comparing group $A$ and group B's variability. The $S 1$ and $S 2$ subjects were equally narrated that the variability of group $A$ was smaller than group B. However, interestingly, both subjects have different narratives in making decisions. The $\mathrm{S} 1$ subject chose group $\mathrm{A}$ to receive an award, whereas the $S 2$ subject chose group B to receive the award. Therefore, researchers examined more deeply how the process of statistical reasoning based on the narrative.

Based on interviews (the script was available in Appendix 1) between the first researcher and subjects, the $\mathrm{S} 1$ subject explains that 40 students in Group A had scores in the range of 60.5-70.5. While in Group B, 22 students had the scores in the range of $60.5-70.5$. The ability of students in group $A$ is more homogeneous than students in group $B$. Therefore, and the student decided that group A should be entitled to receive the awards. Meanwhile, the subject S2 revealed that the ability of students in group B was more evenly distributed than students in group $A$. This can be seen from the distribution of grades in group $B$ that is not only gathered in the range of grades $60.5-70.5$ but also spread in the range of other grades. Therefore, the subjects decided that group $B$ should be entitled to receive the awards. Subjects narrative in comparing variability and making decisions are shown in Table 5.

Table 5 shows that the $S 1$ subject provides an endorsed narrative in the form of rules related to variability. There are two endorsed narratives used by $\mathrm{S} 1$ subjects in the decision-making process. First, the subject used the definition of variability as a reason for selecting group $A$. The subject revealed that variability is a measure of the spread of data; if the data accumulates in a range of average values, then the data variability is small. Group A variability was smaller than group B. The subject chose students in group A to receive an award. Second, the subject used the interpretation of variability as a reason for choosing group $\mathrm{A}$. The $\mathrm{S} 1$ subject revealed that the ability of students in group $A$ was homogeneous because the students' scores accumulated in a range of average values. The subject's collecting value was seen from the form of a graph that jumped dramatically from 60.5 to 70.5 .

Unlike the case with the S2 subject, he narrated that the grade of students in group B spread and not only accumulated around the average value. Thus, groups of students who have spread scores also have a large size of variability. This large variability category was the benchmark for the subject to chose group B.

In this case, there are two narratives expressed by the $\mathrm{S} 2$ subject, namely the first narrative about the notion of variability and the second narrative about the interpretation of variability. The subject revealed that variability was used to see the spread of data from the mean because the greater the size of the variability, the 
greater the spread of data from the mean. The variability of group $B$ was greater than group $A$. Thus, the subject chose students in group $B$ to receive an award. However, in the second narrative, the subject revealed that the ability of students in class B was more evenly distributed than grade $A$. In the first narrative, the subject chose group $B$ because the distribution of students' scores in group B was more varied than scores of students in group $A$.

Based on the narrative on the S1 and S2 subjects, it can be seen that the narrative expressed by the two subjects is the same in comparing variability. The $\mathrm{S} 1$ subject revealed that group A variability was smaller than group B variability because the grades of students in group A piled around the average. Whereas, the S2 subject revealed that group B's variability was higher than group $A$ (the variability of group $A$ was smaller than group $B$ ) because the value of group $B$ students spread from the average and did not just accumulate around the average. This shows that the two subjects' endorsed narrative is the same in comparing the variability of the two data groups. However, the narrative difference occurred when the subject chose which group had better student ability, whether it has large variability or small variability. The narrative is important because it influences the subject to decide to choose group A or group B. Endorsed narrative expressed by $S 1$ subject states that the distribution of good grades has a small variability because if the variability is small, the ability of students in the group is homogeneous or does not differ significantly from one student with another student. Whereas the $\mathrm{S} 2$ subject revealed that the distribution of good grades was in the group that had large variability because the values of students will spread across each range of grades if the variability was large. In other words, the ability of students in the group is evenly distributed.

The findings in this study indicate that students used two forms of narrative in explaining variability based on the ogive graph, namely a consistent narrative and inconsistent narrative. A consistent narrative can emerge if accompanied by a correct understanding of the concept of variability. To make good statistical reasoning, a consistent narrative is needed in each process of statistical reasoning.

Consistent narrative means that the subject can express endorsed narrative in the form of variability rules in each statistical reasoning process. For example, the subject revealed that the small size variability was interpreted as a homogeneous data distribution. The subject looked at the small variability of student grades that accumulated in the range of average grades. Based on that thought, subjects chose group $A$ to receive an award. In this case, the subject gave a consistent statement about variability, namely a statement of homogeneous student ability and a statement of student grades piled around an average grade. As a result, the narrative about the variability expressed by the subject is also consistent. This consistent narrative can help the subject did the statistical reasoning process correctly. Saletta et al. (2020) also state that narrative plays a vital role in reasoning, problemsolving, and building knowledge.

Meanwhile, inconsistent narrative means that the subject expresses endorsed narrative in the form of variability rules that change or contradict in the process of statistical reasoning. For example, the subject gives a different endorsed narrative when comparing variability in the two data groups and when the subject decides to choose one of the two data groups. When comparing variability, subjects interpret large variability measures as seen from the spread of students' value in each range of grades and not just accumulating in a range of average grades. Thus, if variability is large, students' ability in the group is evenly distributed, or the abilities of students are not too different from each other. On the contrary, in making a decision, the subject revealed that the variability of group $B$ was greater than the variability of group $A$ because the students' score in group B spread. Based on that significant variability, subjects chose group $B$ to receive an award. The statement of student ability is equal, and student value spreads are what researchers consider to be two inconsistent statements about variability. As a result, the narrative about the variability he expressed was also inconsistent. In this case, the inconsistent narrative occurred when comparing the variability of two data groups and when making a decision. As a result, the subjects made the wrong decision in choosing one of two data groups. The fatal effect of this inconsistent narrative was also examined by Tasaraf (2018). The finding of his research indicated that students were confused about understanding the material due to the inconsistent narrative explained by the teacher in delivering the subject matter.

Therefore, in order to overcome the inconsistent narrative in statistical reasoning, the students need to have adequate skills in understanding and connecting the statistics concepts. Besides, students who have excellent statistics skills can do statistical reasoning well 
(Rufiana et al., 2018).

The researchers consider that the subject who chose group A because of the smaller variability of group $A$ is a logical narrative compared to the one choosing group $B$. Information about the average value is not enough to determine which group that has more evenly distributed students' score. However, other values are needed, called variability measures, such as standard deviations and variances. A measure of variability is a measure to determine how the spread of a data set from the average (Mann, 2013; Nachmias and Guerrero, 2018). The more data gathered around the average, the smaller the size of the variability. Suppose a lot of data is gathered around the average. In that case, the ability of students in the group is more homogeneous, or it can be said that the students' ability is not much different from one student to another student. Variability can be used to choose one better group of several groups of data (Amaro and Sánchez, 2019; Kramer et al., 2017). For this reason, researchers assess the narrative proposed by subjects who chose group A can do the correct statistical reasoning using a narrative that follows the rules of variability.

In this study, subjects were not only required to determine which variability is higher or smaller than some data groups (Cooper, 2018), but the subjects are also required to narrate the interpretation of large or small variability so that they can make the right decision. Also, subjects were required to connect several concepts to narrate statistical reasoning well, such as linking the variability concepts with the average, median, mode, and normal distribution. If students cannot connect among statistical concepts, it is not easy to properly carry out statistical reasoning processes. The relationship between concepts by the subjects appears when the subjects use the average concept to narrate variability between groups of data. Thus, the ability of the subjects to relate these concepts is essential so that the narratives expressed can help them carry out statistical reasoning well.

This study is limited to the use of narrative in the process of statistical reasoning. Therefore, further research can be conducted by examining statistical reasoning about variability using other commognitive frameworks such as using word use, visual mediator, and routine.

This research is limited to giving questions about variability as much as one question with the normal distribution of data. Other researchers can provide various forms of questions whose data are typically distributed and have a non-normal distribution for further studies. Therefore, researchers can obtain more varied findings related to the statistical reasoning process of students about variability in the narrative perspective.

This study provides the implication that a consistent narrative can help students carry out statistical reasoning about variability successfully. The consistency in the narrative must be supported by understanding the correct concept of variability. Subjects who understand the concept of variability can make a logical narrative in explaining statistical reasoning.

\section{CONCLUSIONS:}

Based on the statistical reasoning process carried out by students in narrating variability in the two data groups on the ogive graph, it can be concluded:

1. There are three statistical reasoning processes performed by the subjects in narrating variability, namely students' narrative in comparing the variability of two data groups, making conclusions, and making decisions.

2. The narrative is a commognitive framework that can be used to investigate in detail how students carry out statistical reasoning processes about variability.

3. Narrative consistency occurs when students can provide an endorsed narrative about the same variability when comparing two groups of data, making conclusions, and making decisions.

4. Narrative inconsistency occurs when students provide an endorsed narrative about opposite variability between comparing two groups of data and choosing one of the two data groups.

5. The consistent narrative plays an essential role in making the right decision. For this reason, the ability and skills to use and connect statistical concepts are needed to produce a consistent narrative.

6. Variability can be used to make decisions in choosing one better group of several groups of data when the data for the two groups are normally distributed.

\section{REFERENCES:}

1. Amaro, J. A. O., and Sánchez, E. A. (2019). Students Reasoning About Variation in Risk Context. In G. Burrill and D. Ben-Zvi (Ed.), Topics and Trends in 
Current Statistics Education Research (pp. 51-69). Springer Nature Switzerland AG. https://doi.org/10.1007/978-3-030-034726_3

2. Bennett, Jeff, Briggs, W. L., and Triola, M. F. (2017). Statistical Reasoning for Everyday Life (Fifth Edi). Kirby Street, London. Pearson Education Limited.

3. Burrill, G., and Biehler, R. (2011). Fundamental statistical ideas in the school curriculum and in training teachers. In $\mathrm{C}$. Batanero, G. Burrill, and C. Reading (Eds.), Teaching statistics in school mathematics: Challenges for teaching and teacher education (A joint ICMI/IASE Study) (pp. 57-69). New York, NY: Springer.

4. Chan, S. W., and Ismail, Z. (2014). Developing a statistical reasoning assessment instrument for high school students in descriptive statistics. Procedia - Social and Behavioral Sciences, 116, 4338-4343.

https://doi.org/10.1016/j.sbspro.2014.01.9 43

5. Coladarci,T, Cobb. C. (2014). Fundamentals of statistical reasoning in education. (Fourth, Ed.). United States of America: John Wiley and Sons, Inc. https://www.researchgate.net/publication/ 267480311_Fundamentals_of_statistical_ reasoning_in_education_4th_ed

6. Cooper, L. (2018). Assessing students understanding of variability in graphical representations that share the common attribute of bars. Journal of Statistics Education, 26(2), 110-124. https://doi.org/10.1080/10691898.2018.14 73060

7. Cooper, L., and Shore, F. S. (2008). Students 'misconceptions in interpreting center and variability of data represented via histograms and stem-and-leaf plots. Journal of Statistics Education, 16(2). https://doi.org/10.1080/10691898.2008.11 889559

8. Cooper, L. L., and Shore, F. S. (2010). The effects of data and graph type on concepts and visualizations of variability. Journal of Statistics Education, 18(2), 1-16. https://doi.org/10.1080/10691898.2010.11 889487

9. Creswell, J. W. (2012). Educational research: Planning, conducting, and evaluating quantitative and qualitative research (P. A. Smith, C. Robb, and M. Buchholtz (eds.); Fourth Edi). Boylston Street, Boston. Pearson Education, Inc. https://doi.org/10.1017/CBO97811074153 24.004

10. DelMas, R. C., and Liu, Y. (2007). Students' conceptual understanding of the standard deviation. In M. C. Lovett and P. Shah (Eds.), Thinking With data (pp. 87116). Mahwah, New Jersey: Lawrence Erlbaum Associates, Inc.

11. Ekol G., Sinclair N. (2016). Undergraduate students' conceptions of variability in a dynamic computer-based environment. In Ben-Zvi D., Makar K. (Ed), The Teaching and Learning of Statistics. (pp.193-203). Springer, Cham. https://doi.org/10.1007/978-3-31923470-0_25

12. Few, S., and Edge, P. (2009). Statistical narrative telling compelling stories with numbers. Visual Business Intelligence Newsletter, 1-10. https://www.perceptualedge.com/articles/v isual_business_intelligence/statistical_nar rative.pdf

13. Gagnier, J. J., and Morgenstern, H. (2017). Misconceptions, misuses, and misinterpre tations of $p$ values and significance testing. Journal of Bone and Joint Surgery American Volume, 99(18), 1598-1603. https://doi.org/10.2106/JBJS.16.01314

14. Garfield, J. B., and Ben-zvi, D. (2008). Developing students' statistical reasoning.USA. Springer New York. https://doi.org/10.1007/978-1-40208383-9

15. Garfield, J., and Ben-Zvi, D. (2009). Helping students develop statistical reasoning: Implementing a statistical reasoning learning environment. Teaching Statistics, $31(3), \quad$ 72-77. https://doi.org/10.1111/j.14679639.2009.00363.x

16. Gastwirth, J. L. (1988). Statistical 
Reasoning in Law and Public Policy (2nd ed.). Boston, San Diego, New York. Academic Press, Inc.

17. Hjalmarson, M. A., Moore, T. J., and Delmas, R. (2011). Statistical analysis when the data is an image: Eliciting student thinking about sampling and variability. Statistics Education Research Journal, 10(1), 15-34.

18. Hidayanto, E., and Rahmatina, D. (2020). Characteristics of student statistical reasoning in mathematical problemsolving. In AIP Conference Proceedings (Vol. 2215,03002, pp. 1-11). AIP Publishing. Retrieved from https://doi.org/10.1063/5.0003653

Published.

19. Hoerl, R., and Snee, R. (2012). Statistical thinking: Improving business performance (Second Edi). Hoboken, New Jersey. John Wiley and Sons, Inc.

20. Ismail, Z., and Wei, S. (2015). Malaysian students' misconceptions about measures of central tendency: an error analysis. In The 2nd ISM International Statistical Conference. AIP Conference Proceedings (Vol. https://doi.org/10.1063/1.4907430

21. Jones, G. A., Langrall, C., Mooney, E. S., and Thornton, C. A. (2004). Models of development in statistical reasoning. In Ben-Zvi Dani and Garfield Joan (Ed.), The Challenge of Developing Statistical Literacy, Reasoning, and Thinking (pp. 97116). Springer Science+Business Media, B.V. https://doi.org/10.1198/tas.2006.s39

22. Kalobo, L.(2016). Teachers' perceptions of learners' proficiency in statistical literacy, reasoning, and thinking. African Journal of Research in Mathematics, Science and Technology Education,20(3), 225-233. https://doi.org/

10.1080/18117295.2016.1215965

23. Karupiah, P. (2015). Teaching research methods : common misconceptions related to random sampling. In USM International Conference on Social Sciences (USMICOSS) 2015 (pp. 280-282). https://www.academia.edu/21483523/Tea ching_research_methods_common_misc onceptions_related_to_random_sampling

24. Khazanov, L and Prado, L. (2010). Correcting students ' misconceptions about probability in an introductory college statistics course. ALM International Journal, 5(June), 23-35. https://files.eric.ed.gov/fulltext/EJ1068215. pdf

25. Kramer, R. S. S., Telfer, C. G. R., and Towler, A. (2017). Visual comparison of two data sets: Do people use the means and the variability? Journal of Numerical Cognition, 3(1), 97-111. https://doi.org/10.5964/jnc.v3i1.100

26. Lampen, E. (2015). Teacher narratives in making sense of the statistical mean algorithm. Pythagoras, 36(1), 1-12. https://doi.org/10.4102/pythagoras.v36i1.2 81

27. Mann, P. S. (2013). Introductory Statistics (J. Dingle, E. Keohane, and B. Pearson (eds.); Eighth Edi). John Wiley and Sons, Inc. River Street, Hoboken.

28. Mueller, S. M., Schiebener, J., Delazer, M., Brand, M., and Brand, M. (2018). Risk approximation in decision making: approximative numeric abilities predict advantageous decisions under objective risk. Cognitive Processing, (0123456789). https://doi.org/10.1007/s10339-018-08549

29. Nachmias, C. F., and Guerrero, A. L. (2018). Social Statistics for a Diverse Society (J. Lasser, J. Miller, and A. Wilson (eds.); Eighth Edi). Mathura Road, New Delhi: SAGE Publications Asia-Pacific Pte. Ltd. https://doi.org/10.2307/3211436

30. Nardi, E. (2016). Where form and substance meet: using the narrative approach of re-storying to generate research findings and community rapprochement in (university) mathematics education. Educational Studies in Mathematics, 92(3), 361-377. https://doi.org/10.1007/s10649-0159643-x

31. National Council of Teachers of Mathematics. (2000). Principles and standards for school mathematics. 
Reston, VA:Author.

32. Noll, J., Clement, K., Dolor, J., Kirin, D., Petersen, M., and Noll, J. (2018). Students ' use of narrative when constructing statistical models in TinkerPlots. ZDM, $O(0), \quad 0$. https://doi.org/10.1007/s11858018-0981-x

33. Pfannkuch, M. (2011). The role of context in developing informal statistical inferential reasoning: A classroom study. Mathematical Thinking and Learning, 13(1-2), 27-46.

34. Rahmatina, D., and Zaid, N.M.(2019). Students' misconceptions in interpreting the mean of the data presented in a bar graph. International Journal of Insight for Mathematics Teaching.,2(1),57-74. http://journal2.um.ac.id/index.php/ijoimt/ar ticle/view/7114/pdf

35. Reading, C., and Reid, J. (2007). Reasoning about variation: student voice. International Electronic Journal of Mathematics Education, 2(3), 110-127. https://www.iejme.com/download/reasonin g-about-variation-student-voice.pdf

36. Roberts, A., and le Roux, K. L. (2019). A commognitive perspective on Grade 8 and Grade 9 learner thinking about linear equations. Pythagoras, 40(1), 1-15. https://doi.org/10.4102/PYTHAGORAS.V4 011.519

37. Roth, W., and Temple, S. (2014). On understanding variability in data: a study of graph interpretation in an advanced experimental biology laboratory. Educ Stud Math, 86, 359-376. https://doi.org/10.1007/s10649-014-95355

38. Rufiana, I. S., Sa'dijah, C., Subanji, S., Susanto, H., and Abdur Rahman Asari. (2018). Informal statistical reasoning of students taken formal statistics learning related to distribution. International Journal of Insight for Mathematics Teaching, 01(2), $130-140$.

39. Saidi, S.S, Siew,N.M,(2019). Reliability and validity analysis of statistical reasoning test survey instrument using the rasch measurement model. International
Electronic Journal of Mathematics Education, 14(3),535-546.

https://doi.org/10.29333/iejme/5755

40. Saletta, M., Kruger, A., Primoratz, T., Barnett, A., Van Gelder, T., and Horn, R. E. (2020). The role of narrative in collaborative reasoning and intelligence analysis: A case study. PLOS ONE, 15(1), $1-17$.

41. Sánchez, E., Silva, C. B. da, and Coutinho, C. (2011). Teachers ' Understanding of Variation. In C. Batanero, G. Burrill, and C. Reading (Eds.), Teaching Statistics in School Mathematics-Challenges for Teaching and Teacher Education: A Joint ICMI/IASE Study (pp. 211-221). México D.F., Mexico Springer Science+Business Media B.V.

42. Sfard, A. (2008). Thinking as communicating: Human development, the growth of discourses, and mathematizing. New York, NY: Cambridge University Press.

43. Swidan, O, and Daher, M. W. (2019). Low achieving students' realization of the notion of mathematical equality with interactive technological artifacts. Eurasia Journal of Mathematics, Science and Technology Education, 15(4), 1-15. https://doi.org/https://doi.org/10.29333/ejm ste/103073

44. Tasara, I. (2017). Commognitive analysis of a teacher's mathematical discourse on the derivative. In Proceedings of the British Society for Research into Learning Mathematics 37(3). pp. 1-6). https://bsrlm.org.uk/wpcontent/uploads/2017/12/BSRLM-CP-373-12.pdf

45. Tasara, I. (2018). Making sense of the teaching of calculus from a commognitive perspective. Proceedings of the 42nd Conference of the International Group for the Psychology of Mathematics Education, 1, 267-274

46. Tempelaar, D. T., Gijselaers, W. H., Loeff, S. S. Van Der, Tempelaar, D. T., and Gijselaers, W. H. (2006). Puzzles in Statistical Reasoning Puzzles in Statistical Reasoning. Journal of Statistics Education 
ISSN:, 14(1), 1-26.

https://doi.org/10.1080/10691898.2006.11

910576

47. Toscano, Rocío, José María GavilánIzquierdo, V. S. (2019). A study of preservice primary teachers ' discourse when solving didactic- a study of pre-service primary teachers ' discourse when solving didactic-mathematical tasks. Eurasia Journal of Mathematics, Science and Technology Education, (May). https://doi.org/10.29333/ejmste/108631

48. Waigandt, A., and Wang, Z. (2010). An Introduction to Statistical Reasoning in Quantitative Research Third Edition (Third Edition, Issue January 2010). Morris Publishing. Kearney, Nebraska.

49. Wells, J. F. (2018). Dot plots and hat plots: supporting young students emerging understandings of distribution, center, and variability through modeling. ZDM, 50(7), 1125-1138.

https://doi.org/10.1007/s11858-018-09611

50. Zayyadi,M, Nusantara,T. Subanji, Hidayanto, E., Sulandra, I.M. (2019). A commognitive framework: the process of solving mathematical problems of middle school students. International Journal of Learning, Teaching and Educational Research.18(2), pp. 89-102. https://doi.org/10.26803/ijlter.18.2.7 
Table 1. Statistical Reasoning Indicators Employed in this Study

\begin{tabular}{lll}
\hline & \multicolumn{2}{c}{ Indicators } \\
\cline { 2 - 4 } Process & Jones et al. (2004) & This Study \\
\hline Analyzing & (a) using mathematical & (a)Narrating the differences \\
ond & $\begin{array}{l}\text { operations to combine, } \\
\text { integrate, and compare data } \\
\text { (b) make inferences and }\end{array}$ & $\begin{array}{l}\text { displayed in ogive form using } \\
\text { statistical narrative }\end{array}$ \\
Interpretin & predictions from the data. & (b) Narrating a conclusion of a \\
& & $\begin{array}{l}\text { group of data or the given data } \\
\text { presentation }\end{array}$ \\
& (c) Narrating a decision based \\
& on the differences and \\
& conclusion among groups of \\
& data
\end{tabular}

Table 2. Profile of participants and subjects in this study

\begin{tabular}{lllcll}
\hline & Gender & Semester & The number & Subtotal & Total \\
\hline Number of & Male & Fourth & 14 & 26 & \multirow{2}{*}{108} \\
participants & & Sixth & 12 & & \\
& \multirow{2}{*}{ Female } & Fourth & 38 & 82 & \multirow{2}{*}{49} \\
& & Sixth & 44 & & \\
\hline Number of & Male & Fourth & 5 & 9 & \\
subjects & & Sixth & 4 & \multirow{2}{*}{40} & \\
& \multirow{2}{*}{ Female } & Fourth & 15 & & \\
& & Sixth & 25 & &
\end{tabular}

Table 3. Narrative of subjects in making decisions

\begin{tabular}{ll}
\hline Decision & Narrative of students on the ogive graph \\
\hline $\begin{array}{l}\text { Group A } \\
(25 \text { subjects })\end{array}$ & $-\begin{array}{l}\text { A drastically rose } \\
\text { (25 subjects) }\end{array}$ \\
& $\begin{array}{l}\text { Group A variability is smaller than group B } \\
\text { ( } 1 \text { subject) }\end{array}$ \\
& $\begin{array}{l}\text { Group A variability is greater than group B } \\
(24 \text { subjects) }\end{array}$ \\
\hline $\begin{array}{l}\text { Group B } \\
\text { (24 subjects) }\end{array}$ & $\begin{array}{l}\text { B statically rose } \\
\text { (24 subjects) }\end{array}$ \\
& The variability of group B is greater than group A (24 subjects)
\end{tabular}


Table 4. Interview guidelines in this study

\begin{tabular}{|c|c|}
\hline Indicators & Questions \\
\hline Describing data & $\begin{array}{l}\text { 1. What do } x \text { and } y \text { axes mean in graphic ogive? } \\
\text { 2. What was the initial step that came to your mind to work on the } \\
\text { problem? } \\
\text { 3. What do you mean by the problem that mean, median, and mode } \\
\text { are the same in a group or between groups? } \\
\text { 4. How did you think about the problem? }\end{array}$ \\
\hline Com & 5. $\mathrm{Wh}$ \\
\hline variak & $\begin{array}{l}\text { s the use of variability? } \\
\text { group has the greatest variability? }\end{array}$ \\
\hline $\begin{array}{l}\text { Making conclusions about the } \\
\text { variability of the two groups }\end{array}$ & 8. Which one is better data spread or centralized? \\
\hline Making decisions & $\begin{array}{l}\text { 9. Which group should receive the award? } \\
\text { 10. Which group of students have the better ability? }\end{array}$ \\
\hline
\end{tabular}

Table 5. Subjects narrative in making comparisons and making decisions

\begin{tabular}{l|l|l}
\hline Subject & Make a graph comparison & Make a decision \\
\hline S1 & $\begin{array}{l}\text { The lines on the group A ogive } \\
\text { jumped up dramatically from } 60.5 \text { to } \\
70.5 .\end{array}$ & $\begin{array}{l}\text { Awards should be given to } \\
\text { students in group A because } \\
\text { Group A variability is smaller than } \\
\text { gradents score a lot in the range of } 60.5 \text { to } 70.5 .\end{array}$ \\
$\begin{array}{l}\text { The ability of students in group A is } \\
\text { more homogeneous than the ability of } \\
\text { students in group B. }\end{array}$ & \\
S2 & $\begin{array}{l}\text { The line in group B ogive rises } \\
\text { statically from } 60.5 \text { to 70.5. } \\
\text { Student scores spread across each } \\
\text { range of grades, not only piling up in } \\
\text { a range of } 60.5 \text { to } 70.5 \text { grades. } \\
\text { The ability of students in group B is } \\
\text { more evenly distributed than students } \\
\text { in group A. }\end{array}$ & $\begin{array}{l}\text { Awards should be given to } \\
\text { students in group B because B } \\
\text { group variability is more } \\
\text { significant than group A }\end{array}$ \\
\hline
\end{tabular}


The "Positive Ogive" graph below shows the distribution of mathematics test scores of two groups of students (Group A and Group B) who have the same mean, median, and mode within and between groups. The school will give an award to one of the two groups based on the of variability.

Group A

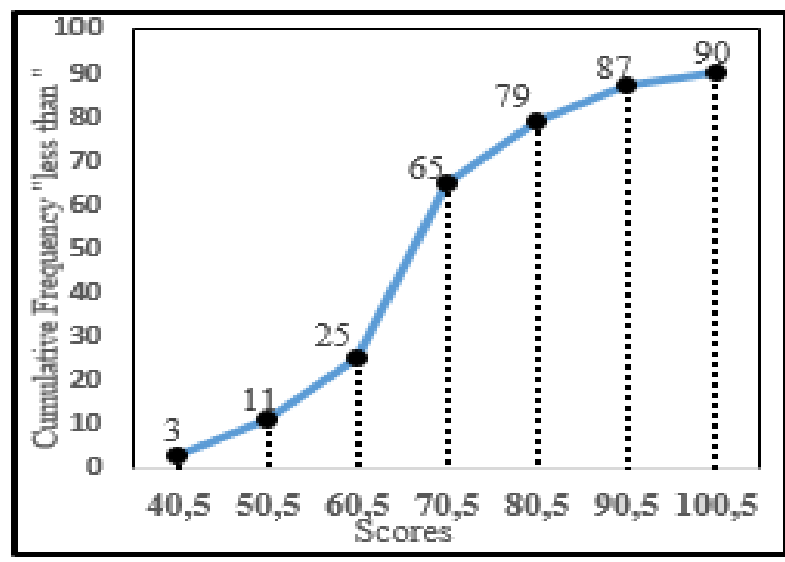

Group B

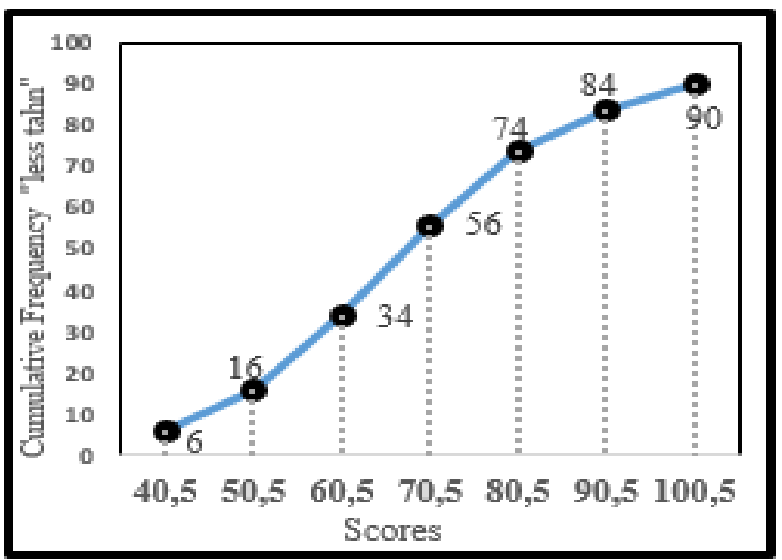

Based on the distribution of values on the "positive ogive "of the above two groups, which group should receive awards from the school? State your reason.

Figure 1. The task of variability in this study

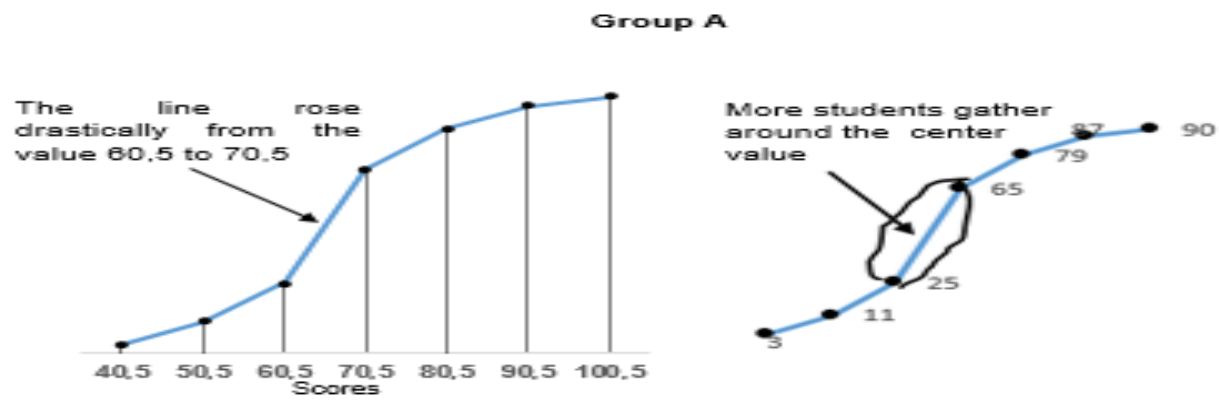

Group B
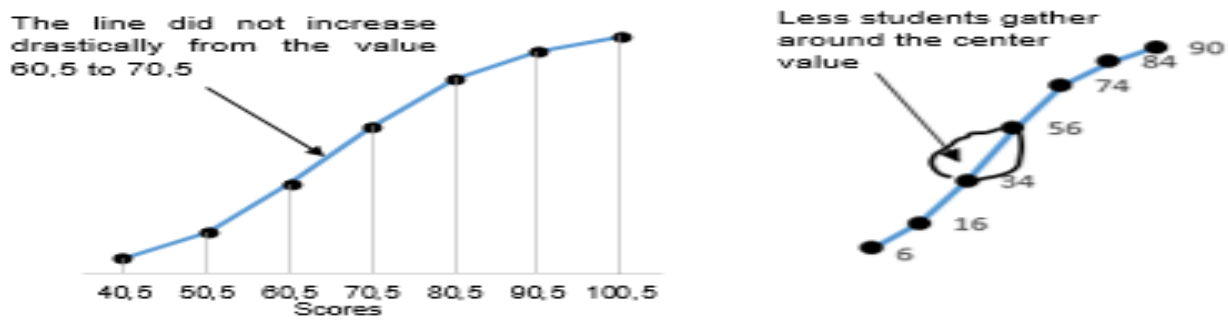

Figure 2. One of forty-nine students answer to compare the variability of two data groups 


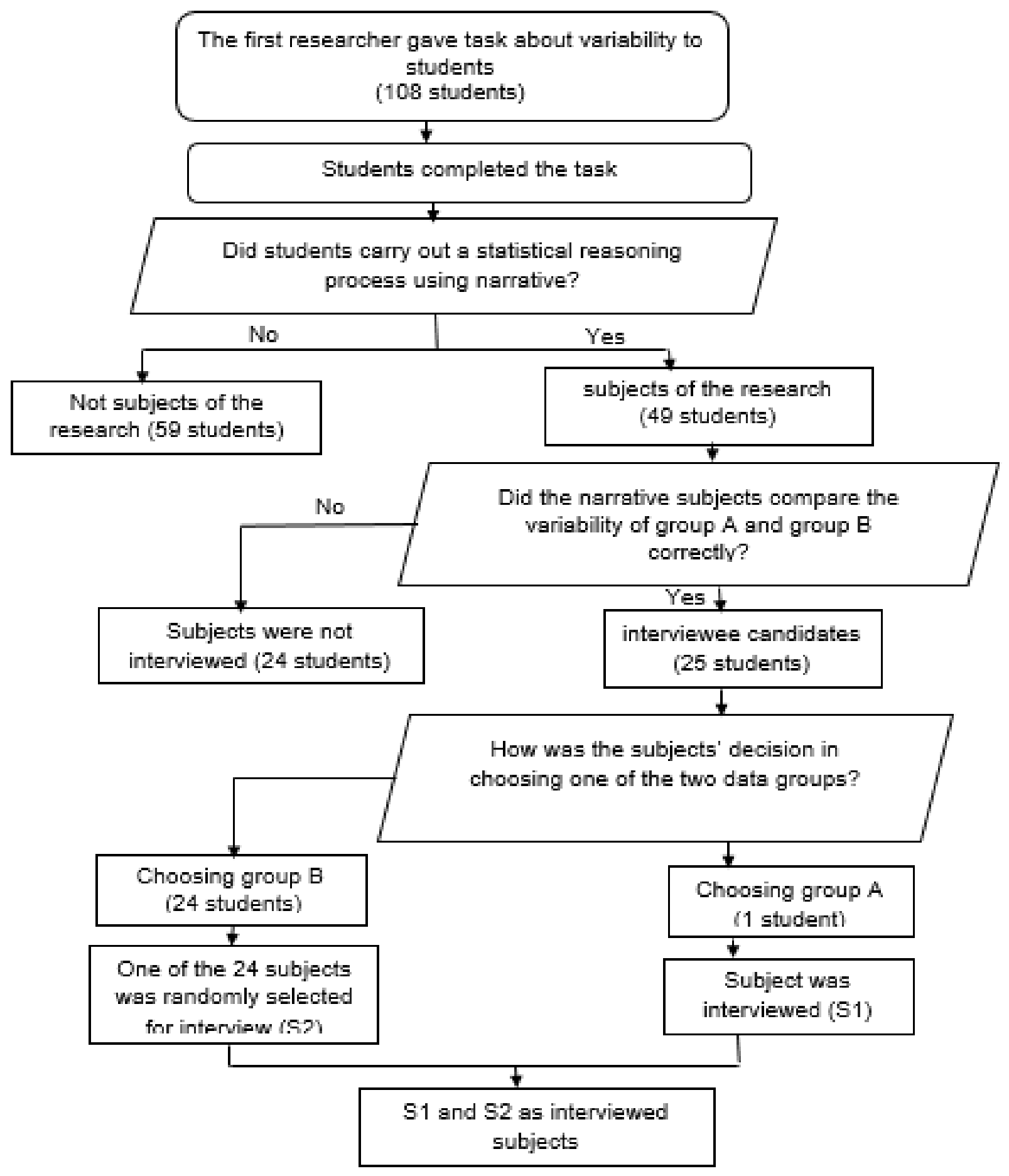

Figure 3. The procedure for selecting research subjects 


\section{APPENDIX 1}

\section{A script of the interview the first research (R) with Student S1 (S1)}

R: How are you?

S1 : Fine, Ma'am,

$\mathrm{R}$ : I want to interview you regarding your answers to the task that you completed. Are you ready?

S1: Yes, Ma'am,

$\mathrm{R}$ : I give you times to look back at the answer you wrote, Ok?

S1: (S1 pays attention to the answer paper that she made)

$\mathrm{R}$ : Are you ready to be interviewed?

S1: yes, Ma'am

$\mathrm{R}$ : What do $\mathrm{x}$ and $\mathrm{y}$ axes mean in ogive?

S1: $X$ axis, $h m m m$..... the upper class boundaries, $Y$ axis number of students are less than the upper class boundaries.

$\mathrm{R}$ : What else can be read from ogive?

S1: Hmm what is it? Hmm.. Where the center is and how many it is, whether it increases sharply (while pointing to the graph of group A) or perhaps like this (pointing to graphic ogive of group B). Is it dynamic Ma'am, while this one increases sharply (pointing to ogive of group A), increase dramatically, there is a big gap.

$\mathrm{R}$ : What was the initial step that came to your mind to work on the problem?

S1: Firstly, I began with writing cumulative frequency with curvature, given a mark value of less than 40.5 is 3 , less than 50,5 is 11 , and so on until less than 100.5 is 90 . Next, I made the frequency of each value to prove the number of students as 90 . Then it was said that the school would give awards to groups based on variability.

R: How did you do it?

S1: Well 90 students means the middle value is at 45 . Then I looked for the $45^{\text {th }}$ student to be at what value, meaning the $45^{\text {th }}$ student is in which grade, in which class, the class boundaries, so the 45th student was between frequency of 25 and 65 in the group $A$, and between frequency of 34 and 56 in the group $B$ at the class boundary $60.5-70.5$. So, more students are in group $A$, there are 40 students, while in group $B$, there are 22 students at the class boundary $60.5-70.5$.

$\mathrm{R}$ : What do you mean by the problem that mean, median, and mode are the same in a group or between groups?

S1: For example, the mean is 65 , and therefore the median and mode is also 65.

$\mathrm{R}$ : What are the measure of variability that you know?

$\mathrm{S} 1$ : Hmmm ... there is a standard deviation, there is another range ... there is one more ... I didn't remember, Ma'am...

$\mathrm{R}$ : What is the use of variability?

S1: To find out whether the extent of data distribution is far or not.

$\mathrm{R}$ : How do we know that the distribution is far?

S1: It is far. We can see from the centre, Ma'am.

$\mathrm{R}$ : Which group has the greatest variability?

S1: Group B, Ma'am

R: why?

S1: because in group B fewer students were in the center of the data than group A, Ma'am

$\mathrm{R}$ : which one is better data spread or centralized?

S1: Center, Ma'am

$\mathrm{R}$ : Which group should receive the award?

S1: Group A, Ma'am.

$\mathrm{R}$ : Why was it decided that group A should get an award?

S1: Because it increases sharply in the centre of the data, so more students are at the class boundary $60.5-70.5$, so that the ability is more homogeneous.

\section{A script of interview the first research (R) with Student S2 (S2)}

R: How are you?

S2 : Fine, ma'am, 
$\mathrm{R}$ : I want to interview you regarding your answers to the task that you completed. Are you ready?

S2 : Yes, ma'am,

$\mathrm{R}$ : I give you times to look back at the answer you wrote, Ok?

S2 : (S2 pays attention to the answer paper that he made)

$\mathrm{R}$ : Are you ready to be interviewed?

S1: yes, Ma'am

$\mathrm{R}$ : What was the initial step that came to your mind to work on the problem?

S2: I read the problem, and I noticed the ogive graph form

$\mathrm{R}$ : What does number 3 mean in the ogive of group A?

S2: There are 3 students whose scores are under 40.5 .

$\mathrm{R}$ : What does number 11 mean in the ogive in group $A$ ?

S2: There are 11 students under 50.5 .

R: How did you think about the problem?

S2: I saw graphical form between groups $A$ and $B$, some increase sharply.

$\mathrm{R}$ : What do you mean by the problem that mean, median, and mode are the same in a group or between groups?

S2 : Group A has the same mean, median, and mode. The mean, median, and mode values in group

B were the same as for group A, Ma'am.

$\mathrm{R}$ : What is variability?

S2: The spread value is more to the standard deviation.

$\mathrm{R}$ : What's the function?

S2: To see the data distribution spreads widely or not.

$\mathrm{R}$ : which one is better data spread or centralized?

S2: Spreading, Ma'am

R: Why?

S2: If the data is spread out, it means that the distribution of the scores is balanced ma'am, students who get high, medium, and low scores are balanced, the data do not just accumulate in the middle score, ma'am.

$\mathrm{R}$ : What is the middle score?

S2: between the scores 60.5-70.5 Ma'am

R: Which group has better student ability?

S2 : Group B, Ma'am

R: Why?

S2: because the students' abilities were almost the same in group $B$, the scores were even

$\mathrm{R}$ : Which group has the greatest variability?

S2: Group B, Ma'am

R: Why?

S2: because of the lines in the group B graph increase in statically Ma'am. The scores do not just accumulate in the centre; however, the scores were spread out equally.

$\mathrm{R}$ : Which group should receive the award?

S2: Group B, Ma'am.

$\mathrm{P}:$ Why?

S2: Because the variability of group $B$ was greater than group $A$, and the increase of ogive form of group B spreads up, ma'am, not gathering like group A 